\title{
JĘZYK ODZIEDZICZONY A DWUJĘZYCZNOŚĆ - O KONIECZNOŚCI BADAŃ KOMPARATYWNYCH
}

\begin{abstract}
Słowa kluczowe: język odziedziczony, dwujęzyczność kognitywna, potrzeba badań komparatywnych
\end{abstract}

Streszczenie. Przeobrażenia społeczno-ekonomiczne towarzyszące globalizacji sprawiły, że biografie językowe oraz przeszłość edukacyjna polskich dzieci stały się bardziej złożone. Obserwacje i prace badawcze pokazują, że znaczna część uczniów jest dwujęzyczna, zazwyczaj stosunkowo szybko przyswajają bowiem język kraju zamieszkania, zachowując lub poznając jednocześnie polszczyznę. Stopień jej znajomości może być jednak dość zróżnicowany ze względu na brak możliwości stałego i bezpośredniego z nią kontaktu. W rezultacie większą część młodych ludzi o polskich korzeniach cechuje dwujęzyczność naturalna, znacznie rzadziej natomiast ich udziałem jest dwujęzyczność kognitywna.

W niniejszym artykule zjawisko dwujęzyczności będziemy rozważać na płaszczyźnie glottodydaktycznej. Zwrócimy również uwagę na konieczność badań komparatywnych kompetencji lingwistycznych osób bilingwalnych. Poszerzyłyby one naszą wiedzę o dwujęzyczności, w szczególności zaś o rzadko badanej - kognitywnej. Przyniosłyby również pełniejszą charakterystykę JOD jako fenomenu plasującego się językiem ojczystym a obcym, a ich wyniki znalazły zastosowanie nie tylko w glottodydaktyce, czy socjo- i psycholingwistyce, lecz także w edukacji.

\section{WSTĘP}

W wyniku przeobrażeń społecznych towarzyszących globalizacji w ostatnich dekadach znacząco nasiliło się zjawisko migracji rodzin. Spowodowało ono, że biografie językowe oraz przeszłość edukacyjna ${ }^{1}$ polskich dzieci stały się bar-

*ewa.lipinska@uj.edu.pl, Uniwersytet Jagielloński, Wydział Polonistyki, Katedra Języka Polskiego jako Obcego, ul. Grodzka 64, 31-044 Kraków; anna.barbara.seretny@uj.edu.pl, Uniwersytet Jagielloński, Wydział Polonistyki, Katedra Języka Polskiego jako Obcego, ul. Grodzka 64, 31-044 Kraków.

${ }^{1}$ Przeszłość edukacyjna jest pojęciem obejmującym historię edukacji ucznia we wszystkich szkołach i placówkach oświatowych, do których uczęszczał; przez biografię językową rozumie się rejestr wydarzeń oraz doświadczeń związanych z nauką i/lub opanowywaniem języka/języków. 
dziej złożone. Zanurzenie w obcym żywiole językowym, które jest konsekwencją zmiany miejsca zamieszkania, sprawia, że ich polszczyzna nie może się rozwijać równie intensywnie jak w Polsce ze względu na zbyt małą ilość danych językowych, które do nich docierają, a także ich niewielkie zróżnicowanie (limited input). Ograniczony kontakt (limited exposure) z kodem macierzystym prowadzi zaś do tego, że traci on swoją prymarną funkcję, stając się językiem ojczystym jako drugim, czyli odziedziczonym (heritage language).

Pobyt poza granicami kraju stwarza niepowtarzalną szansę osiągnięcia dwujęzyczności - zwłaszcza dla osób młodych (dzieci i młodzieży)², pod warunkiem jednak, że zachowają i będą rozwijać swoją polszczyznę, bo język kraju osiedlenia, za sprawą edukacji szkolnej, opanowują stosunkowo szybko w takim samym lub podobnym stopniu co rodzimi jego użytkownicy.

W niniejszym artykule zjawisko dwujęzyczności, jej rodzaje, uwarunkowania (ze szczególnym uwzględnieniem istoty języka odziedziczonego) będziemy rozważać na płaszczyźnie glottodydaktyki. Zwrócimy także uwagę na konieczność komparatywnych badań kompetencji młodych użytkowników polszczyzny. Analizy podobieństw i różnic między językiem jako ojczystym, odziedziczonym i obcym poszerzyłyby wiedzę językoznawców, w tym psycho- i socjolingwistów, glottodydaktyków oraz pedagogów, ukazując je expressis verbis, co w konsekwencji przyczyniłoby się do ulepszania metod i technik nauczania oraz konstruowania pomocy dydaktycznych w taki sposób, aby odpowiadały rzeczywistym potrzebom uczących się. Możliwa stałaby się także pełniejsza charakterystyka jakościowa i ilościowa tych zjawisk, które obecnie zyskują nowy wymiar w edukacji.

\section{JEZZYK ODZIEDZICZONY}

Języki, które nie są dominujące (urzędowe) w danym państwie, często marginalizowano, a nawet deprecjonowano. Obecnie jednak w większości krajów zdobywają odpowiednią pozycję w systemie edukacji i polityce oświatowej (zgodnie $\mathrm{z}$ trendem zarzucania wymogów asymilacji imigrantów, a stosowania podejścia integracji ${ }^{3}$ ). Języki te często określa się mianem odziedziczonych (heritage languges), a nie jak dotąd - domowych, mniejszościowych czy etnicznych (home, mi-

${ }^{2}$ Omówienie tego zjawiska w polskiej literaturze przedmiotu można znaleźć w pracach, m.in.: Czykwin, Misiejuk 2002; Lipińskiej 2003, 2013; Miodunki 2003, 2010; Wróblewskiej-Pawlak 2004; Kurcz (red.) 2007; Wodnieckiej 2011; Kurcz, Okuniewskiej (red.) 2011.

${ }^{3} \mathrm{~W}$ krajach z długą tradycją przyjmowania imigrantów dostrzega się w ich etniczności duży potencjał, który może wzbogacić kulturę rodzimą, wpływając jednocześnie na poszerzanie horyzontów wszystkich mieszkańców. 
nority, etnic languages ${ }^{4}$ ). Zdaniem Fishmana (2001), terminu język odziedziczony (dalej: JOD ${ }^{5}$ ) można używać w stosunku do:

- języków imigrantów, którzy osiedlili się w danym kraju (np. tureckiego w Niemczech);

- języków natywnych na danym terytorium, które są zagrożone wymarciem wskutek relokacji użytkowników (np. języka karaczajsko-bałkarskiego w Rosji) czy kolonizacji terenów (np. języka navaho w USA);

- języków osadników/kolonizatorów, którzy podbili dane terytorium, osiedlili się na nim i w dalszym ciągu je zamieszkują jako mniejszości (np. francuskiego w Maroku).

JOD służy do porozumiewania się głównie w środowisku domowym. Ulega znaczącemu wpływowi języka kraju osiedlenia, który, zwłaszcza dla zerowego i pierwszego pokolenia ${ }^{6}$, często staje się kodem funkcjonalnie pierwszym (zob. Cieszyńska 2006), spychając J1 na drugi (lub dalszy) plan. Jest tworem specyficznym, sytuującym się de facto między językiem ojczystym a obcym (zob. Valdés 2000, 2001; Montrul 2013; Lipińska, Seretny 2012a, 2012b, 2012c). Z ojczystym łączy go cel i sposób przyswajania, gdyż służy do komunikacji z najbliższym otoczeniem i jest nabywany drogą słuchowo-ustną; podobnie jak J1 jest też nośnikiem tożsamości oraz wykładnikiem więzi grupowej. Do języka obcego zbliża go zaś kontekst, w którym się pojawia, oraz zakres, w jakim się go wykorzystuje, a także fakt, że jego użytkownicy rzadko osiągają w nim biegłość (zob. Lipińska, Seretny 2012a; Seretny, Lipińska 2016). 'Przełączają' się bowiem na język kraju osiedlenia, który szybko zyskuje absolutną przewagę nad JOD (na przykład, dzieci polskich emigrantów w USA przestawiają się na angielski, który jest językiem ich edukacji).

Język odziedziczony jest zatem językiem 'swoim', bo służy do komunikacji z bliskimi, lecz też i 'nieswoim', gdyż nie stanowi w pełni sprawnego narzędzia porozumiewania się. Jego użytkownicy mają spore braki', które uwidoczniają się zwłaszcza na płaszczyźnie lingwistycznej.

${ }^{4}$ Słusznie uznano bowiem, że określenia te pozbawiały je historyczno-kulturowo-emocjonalnego tła, stanowiącego o ich istocie i o znaczeniu, jakie mają dla użytkowników (zob. Fishman 2001).

${ }^{5}$ W Niemczech lansowane jest określenie ,język pochodzenia”. Pisze o tym Gębal (2018).

${ }^{6}$ Pokolenie zerowe - dzieci, które opuszczają ojczyznę wraz z rodzicami, urodzone w kraju. Pierwsze pokolenie emigracyjne - dzieci urodzone na obczyźnie (zob. m.in. E. Lipińska 2007, 2013).

${ }^{7}$ Kompetencje użytkownika języka, które decydują o jego sprawności komunikacyjnej, obejmują kompetencje ogólne i językowe, tj. lingwistyczne, socjolingwistyczne i pragmatyczne. Kompetencje lingwistyczne to znajomość i umiejętność stosowania formalnych środków językowych w celu sformułowania poprawnych i sensownych wypowiedzi. Kompetencje socjolingwistyczne umożliwiają użytkownikom dostosowywania wypowiedzi do konsytuacji, dzięki nim zachowany jest społeczny wymiar komunikacji. Kompetencje pragmatyczne - to znajomość zasad organizacji przekazu językowego, umiejętność ich zastosowania w celu wypełnienia określonej funkcji komunikacyjnej (zob. ESOKJ 2003). 
W zakresie gramatyki posługujący się JOD znają jedynie część konstrukcji, a w tych, które stosują, popełniają błędy (część odstępstw od normy może być wynikiem interferencji). $Z$ dotychczasowych badań empirycznych (zob. np. Polinsky 1997; Polinsky, Kagan 2007 - dla języka rosyjskiego) i obserwacji glottodydaktycznych wynika, że u użytkowników JOD w zakresie systemu gramatycznego często, podobnie jak i u uczących się języka jako obcego, zaznacza się:

a) niepełna internalizacja struktur morfo-syntaktycznych (zob. Laskowski 2009; Żurek, 2016);

b) płytsza internalizacja struktur, nawet tych częściej używanych, która skutkuje brakiem konsekwencji gramatycznej - w tej samej wypowiedzi pojawiają się konstrukcje prawidłowe i niepoprawne, np. sąsiadują w niej właściwe i błędne końcówki tego samego przypadka

c) słabsza znajomość struktur morfo-syntaktycznych rzadziej używanych w języku mówionym (np. w polszczyźnie - celownika liczby pojedynczej rzeczownika, konstrukcji imiesłowowych, strony biernej);

d) nie dość dobrze opanowana lub nieopanowana umiejętność budowania zdań wielokrotnie złożonych oraz nominalizacji wypowiedzeń;

e) nadużywanie zaimków i niektórych spójników itp.

Zasób leksykalny użytkowników JOD ogranicza się do słów najczęściej stosowanych, niejednokrotnie potocznych. W wypowiedziach uwidocznia się więc niedostatek środków wyrazu, powodujący, że stają się one nieporadne, często niespójne, a stopień ich nasycenia treścią (jej nośnikami są leksemy tematyczne) jest co najmniej niewystarczający (zob. Seretny 2015). Mocno zaznacza się też w nich wpływ leksyki języka kraju osiedlenia.

Wymowa użytkowników JOD nosi niekiedy wyraźne znamiona języka kraju zamieszkania ${ }^{9}$, a kontur intonacyjny wypowiedzi pozostaje pod wyraźnym jego wpływem. Część osób nie zna pisanej odmiany języka lub zna ją bardzo słabo, rzadko można więc mówić o opanowaniu kompetencji ortograficznej (zob. Lipińska, Seretny 2012e), a kompozycja i redakcja tekstów bywa odbiciem wersji mówionej. Ograniczenie komunikacji do codziennych kontaktów w kręgu rodziny skutkuje także nieznajomością lub niepełną znajomością rejestrów języka, niektórych konwencji grzecznościowych (niedostatki w zakresie kompetencji socjolingwistycznych), schematów interakcyjnych, a także brakiem umiejętności realizacji wielu funkcji komunikacyjnych (luki w zakresie kompetencji pragmaligwistycznych), zwłaszcza mediacyjnych, działania i ekspresywnych ${ }^{10}$.

${ }^{8}$ Punkty b, c, d: w oparciu o niezweryfikowane dane naukowe (wieloletnie obserwacje, analizy wyniki testów osiągnięć w Centrum Języka i Kultury Polskiej w Świecie UJ, wycinkowe analizy testów biegłości).

${ }^{9}$ Inaczej artykułowane mogą być niektóre głoski (np. dzieci z polskich rodzin wychowywane we Francji często nie realizują polskiego drżącego $r$ ) lub całe ich grupy.

${ }^{10}$ Oczekiwane umiejętności użytkowników na poszczególnych poziomach biegłości precyzują programy nauczania języka polskiego (zob. Janowska i in. (red.) 2011). 
Na poziom znajomości polszczyzny jej użytkowników wpływają takie czynniki, jak:

- przynależność do określonego pokolenia emigracyjnego (dzieci urodzone w Polsce vs. dzieci urodzone na emigracji);

- liczba lat spędzonych poza Polską;

- język komunikacji rodzinnej;

- uczęszczanie (lub nie) do szkoły polskiej/polonijnej oraz lokalnej w kraju zamieszkania;

- stopień asymilacji rodziców (zob. Lipińska, Seretny 2017).

Reasumując: ci, którzy posługują się JOD, choć sprawiają wrażenie native speakerów, w istocie nimi nie są. Przy bliższym poznaniu ich język okazuje się ubogi leksykalnie, nieadekwatny do wieku i poziomu edukacji; często odstaje od odmiany standardowej ${ }^{11}$. Utrudnia to, a nawet uniemożliwia komunikację z każdym jej uczestnikiem i w każdej sytuacji.

Osoby z pierwszego pokolenia polonijnego zazwyczaj znają JOD głównie w wersji mówionej, dlatego można ich nazywać mówiacymi językiem odziedziczonym (MJOD, na wzór HLS, czyli heritage language speakers), piśmienność jest bowiem na ogół wynikiem nauki szkolnej, a tę zagranicą pobiera w polskich placówkach oświatowych niewiele dzieci - najwyżej 12-15\% (zob. Miodunka i in. (red.) 2018). Powodów, dla których tak się dzieje, jest wiele. Za najważniejszy uznać należy postawę rodziców, bo to od nich zależy, czy dzieci uczęszczają do polskich/polonijnych szkół na obczyźnie. Fakt, że nie posyłają tam swoich pociech często wynika z braku wyobraźni, z niewiedzy, że to może się skończyć znacznym zubożeniem, a nawet zanikiem języka rodzimego. Inną przyczyną jest daleka od nowoczesności organizacja procesu kształcenia czy mało atrakcyjne metody nauczania. Do niedawna też zagraniczny język polski powszechnie był traktowany jak krajowy, w szkołach korzystano więc z materiałów przeznaczonych dla polskich uczniów w Polsce. Nie przystawały one do możliwości ani potrzeb uczących się języka odziedziczonego (UJOD - odpowiednik HLL, czyli heritage language learner). Inną bolączką szkolnictwa polonijnego jest kadra nauczycielska, w wielu przypadkach nieprawidłowo przygotowana do pracy na obczyźnie, niewiedząca, że JOD należy rozwijać nie tak samo jak język ojczysty i że nie można korzystać z tych samych, co dla J1, pomocy dydaktycznych. Nauczanie JOD, ze względu na jego swoistość, powinno łączyć elementy kształcenia charakterystyczne dla J1 i dla JO ${ }^{12}$. Świadomość taka jest jednak coraz bardziej powszechna, a to $-\mathrm{m}$.in. za sprawą warsztatów organizowanych dla nauczycieli polonijnych, a także rozmaitych kursów dydaktycznych, studiów podyplomo-

${ }^{11}$ Jest to więc kod ograniczony (zob. Bernstein 2003).

${ }^{12} \mathrm{~W}$ nauczaniu JOD warto też uwzględniać w szerokim zakresie język i realia kulturowe kraju osiedlenia. Jako jedna z pierwszych podkreślała to Bieńkowska (1974), pisząc, że rzeczywistość, w której żyją dzieci jest nadrzędna w stosunku do polskiej. 
wych. O różnicach między językiem ojczystym a odziedziczonym wiedzą już także przyszli uczący języka polskiego jako obcego, gdyż zagadnienia te są częścią programu kształcenia na studiach magisterskich.

Mrzonką jest jednak oczekiwanie na jeden wspólny program nauczania języka odziedziczonego ze względu chociażby na problem niejednolitości języków polonijnych, Polonie są bowiem różne ${ }^{13} \mathrm{~W}$ zależności od całego szeregu czynników. Za najistotniejsze należy uznać: język kraju osiedlenia i jego moc, stosunek doń imigrantów, co wiąże się z chęcią bądź niechęcią do używania go oraz status Polaków i języka polskiego w kraju osiedlenia. Otwiera to możliwość kultywowania JOD-ów lub ją zamyka. Jedyne więc, o czym można byłoby pomyśleć, to opracowanie czegoś na kształt podstawy programowej, wyznaczającej cele, wskazującej jednocześnie możliwe drogi dojścia do nich, narzędzia, które daje się w trakcie ich realizacji wykorzystać oraz stosowne materiały.

Charakteryzując proces glottodydaktyczny w zakresie nauczania języka polskiego jako odziedziczonego, Gębal (2018, s. 88) podkreśla, że nauczanie dzieci polskich za granicą ma mieć miejsce: w przedszkolach, w szkołach i w ośrodkach kształcenia polonijnego i że powinno być wspierane kulturowo i językowo poza szkołą - w ośrodkach kultury polonijnej. Dla dorosłych osób pochodzenia polskiego zaś należy organizować kursy języka i kultury polskiej w tychże ośrodkach. Autor uściśla jednak, że wszystko zależy od kontekstu praktyczno-naukowo-politycznego, co oznacza, że

sposób jego organizacji oraz przyjmowanych rozwiązań terminologicznych stanowi wypadkową zainteresowania opisywaną (...) problematyką decydentów systemu edukacyjnego, reprezentujących konkretne środowiska polityczne. Oni bowiem dysponują odpowiednimi instrumentami legislacyjnymi i środkami finansowymi, mogącymi rozwijać lub wstrzymywać wcielanie do praktyki nauczania rozwiązań i koncepcji wypracowywanych przez akademików i nauczycieli.

(Gębal 2018, s. 91)

Na koniec podkreślmy, że ze względu na szeroki zakres użycia terminu JOD, posługując się nim, należy zawsze wyraźnie wskazać, do której z wymienionych grup użytkowników ma się odnosić. W glottodydaktyce polonistycznej dotyczy najczęściej języka imigrantów.

\section{DWUJĘZYCZNOŚĆ NATURALNA A KOGNITYWNA}

Badania i obserwacje pokazują, że znaczna część członków pokolenia polonijnego sprawnie włada językiem kraju zamieszkania, posługując się jednocześnie polskim. Znają więc jeden i drugi język lub są dwujęzyczni ${ }^{14}$. W niniejszej

${ }^{13}$ Szerzej o Poloniach i ich językach zob. Lipińska (w druku).

${ }^{14} \mathrm{O}$ rozróżnieniu tych pojęć zob. np. Lipińska 2015a. 
pracy przyjrzymy się dwu rodzajom bilingwizmu: naturalnemu ${ }^{15} \mathrm{i}$ kognitywnemu. Rozróżnia się je na podstawie sposobu opanowania obydwu kodów oraz poziomu ich kompetencji.

Dwujęzyczność naturalna polega na nabywaniu polszczyzny drogą nieformalną i posługiwaniu się nią rutynowo w rodzinie i w kręgu polskiej społeczności w spontanicznych interakcjach ustno-słuchowych przy jednoczesnym uczeniu się w szkole języka kraju osiedlenia, który jest używany we wszystkich sferach życia - poza prywatną ${ }^{16}$. Dana jednostka posługuje się więc obydwoma językami w funkcji komunikacyjnej, ale tylko jednym w funkcji poznawczej ${ }^{17}$. Bilingwizm kognitywny natomiast powstaje w wyniku przyswajania wspieranego systematycznym uczeniem się obu kodów. Polega ,na częstym i swobodnym władaniu wszystkimi sprawnościami w języku ojczystym (wyjściowym) i innym (docelowym) w różnych okolicznościach i z różnymi uczestnikami aktu komunikacji. Wiąże się także z bliskim kontaktem z obydwiema kulturami i możliwością ich doświadczania/doznawania" (Lipińska 2015a, s. 57). Bilingwizm kognitywny może zaistnieć dzięki uczestnictwu ucznia w zajęciach szkoły uzupełniającej (sobotniej) przy codziennej komunikacji po polsku oraz przyswajaniu języka za pomocą polskich mediów lub podczas zajęć organizowanych przez różne instytucje polonijne (np. sportowych czy teatralnych prowadzonych po polsku). Język kraju osiedlenia jest przyswajany w najbliższym otoczeniu i poznawany (uczony) w lokalnych placówkach oświatowych, w których imigrant spełnia swój edukacyjny obowiązek (zob. Lipińska, Seretny 2012d). Za wyróżniki bilingwizmu kognitywnego uznać należy przede wszystkim używanie przez daną jednostkę obu języków w funkcji komunikacyjnej i poznawczej oraz znajomość obydwu kodów tak w odmianie mówionej, jak i pisanej (Lipińska 2015a).

Osiągnięcie przez dziecko dwujęzyczności kognitywnej jest procesem długotrwałym, niezachodzącym samoistnie (zob. Petitto 2009). Wymaga dużego zaangażowania najbliższego otoczenia młodego człowieka (rodziców i krewnych ${ }^{18}$ ): codziennych rozmów, nie tylko na tematy związane z życiem powszednim, lecz także czytania książek, uczestnictwa w kulturze. Dziecko powinno być umiejętnie motywowane do wysiłku i otrzymywać wsparcie w działaniach językowych, a przede wszystkim - musi chodzić do szkoły polskiej, czyli miejsca, w którym $\mathrm{w}$ pełni zetknie się z językiem (w wersji standardowej) w funkcji poznawczej.

${ }^{15}$ Dwujęzyczność naturalna nazywana jest również popularna lub ludową; dwujęzyczność kognitywna stanowi swoiste połączenie inteligenckiej/elitarnej. Zob. IEL 1992, s. 176, 183-184; Warchoł-Schlottmann 1994, s. 35; Skutnabb-Kangas 1981, s. 75-76; de Mejía 2002.

${ }^{16}$ Inną jej postacią jest znajomość obydwu języków tylko w postaci ustno-słuchowej, co występuje zazwyczaj u osób niewykształconych lub słabo wyedukowanych.

${ }^{17}$ Analogicznie, przez jednojęzyczność kognitywna rozumie się znajomość tylko jednego języka, który został w pełni opanowany w toku naturalnej interakcji z innymi użytkownikami (język jako narzędzie komunikacji) oraz nauki szkolnej (język jako narzędzie poznania). Jednojęzyczność naturalna jest zaś równoznaczna z posługiwaniem się językiem wyłącznie w odmianie mówionej.

${ }^{18} \mathrm{O}$ roli rodziców w transmisji polskości zagranicą zob. Lipińska 2013, 2014, 2015 b. 
Bilingwizm kognitywny jest więc szczególnym rodzajem dwujęzyczności, którego istnienie daje się obiektywnie stwierdzić; możliwe jest również badanie dynamiki jego rozwoju przez poddanie pomiarowi różnych aspektów biegłości językowej jednostki (Lipińska 2013). Cechuje on znaczną grupę młodych ludzi polskiego pochodzenia zamieszkałych za granicą, sprawnie władają bowiem oni językiem kraju zamieszkania, zachowując lub poznając jednocześnie polski ${ }^{19}$.

\section{KONIECZNOŚĆ BADAŃ DWUJĘZYCZNOŚCI - SZANSE I WYZWANIA}

Kompetencje językowe użytkowników dwujęzycznych nie były dotychczas objęte szerszą refleksją teoretyczną ani szerzej zakrojonymi badaniami empirycznymi. Wydaje się, że zaistniała wręcz konieczność wypełnienia tej luki. Należałoby poddać analizie język nastolatków ${ }^{20}$ pokolenia polonijnego, które dwujęzyczność osiągnęło w warunkach emigracyjnych. Swoistość języka odziedziczonego - znana głównie z opisów, tłumaczeń, obserwacji uczestniczących, niezweryfikowanych danych czy wycinkowych badań - powinna zyskać wyczerpującą charakterystykę ilościową i jakościową. Ważne są więc odpowiedzi na takie pytania, jak:

1. Czy polszczyzna jako język odziedziczony w wymiarze kognitywnym posiada specyficzne cechy w porównaniu z odmianą standardową?

2. Czy polszczyzna może być opanowana przez przedstawicieli pokolenia polonijnego na poziomie podobnym lub porównywalnym do tego, jaki osiągają ich rówieśnicy w Polsce?

3. Czy język kraju osiedlenia został opanowany przez nich na poziomie porównywalnym z tym, jakim legitymują się ich jednojęzyczni rówieśnicy?

W kręgu zainteresowań badaczy (głównie logopedów i psycholingwistów) są przede wszystkim małe dzieci dwujęzyczne, a ich dociekania koncentrują się na procesie akwizycji (zob. Laskowski 2009), stadiach rozwoju obu języków oraz towarzyszących im zaburzeniach (zob. m.in. Cieszyńska 2006; Wodniecka i Haman 2013). Analizie poddawany był też język dorosłych emigrantów. Poszukiwano zmian, jakie w nim następują pod wpływem kodu kraju osiedlenia, tj. odstępstw od odmiany standardowej, nasycenia kalkami, zapożyczeniami, cytatami (zob. m.in. Sękowska 1994; Dubisz (red.) 1997). Ujmowano go także z perspektywy socjologicznej, widząc w nim nośnik tożsamości, więzi grupo-

${ }^{19}$ Dwujęzyczność nie jest zmienną kategorialną typu 0 albo 1. Idealna, tj. taka, w której znajomość obu języków jest identyczna i towarzyszy jej porównywalna częstość użycia każdego z nich, jest zjawiskiem raczej rzadkim, dlatego też należy ją ujmować w kategoriach wielowymiarowego kontinuum (zob. Luk, Bialystok 2013).

${ }^{20}$ Młodsze dzieci trudniej się bada chociażby ze względu na ich niedojrzałość edukacyjną. 
wej (zob. m.in. Miodunka 2003; Wróblewska-Pawlak 2004; projekt Polish your Polish 2016) i zajmowano się postawami wobec polszczyzny (zob. Rabiej 2007; Lipińska, Seretny 2012b) oraz sposobami jej transmisji (zob. Dębski 2009) Warto przy tym nadmienić, iż wszystkie nowsze analizy koncentrowały się głównie na języku Polonii europejskich.

Badania ilościowe pokazujące specyfikę opanowywania poszczególnych podsystemów na niewielkich próbach prowadzili różni badacze. Dębski (2015) sprawdzał stopień opanowania podsystemów fonologicznych J1 i J2 przez małych Australijczyków polskiego pochodzenia ${ }^{21}$. Sprawność pisania (ze szczególnym uwzględnieniem składni) u polskich dzieci w Anglii analizowała Czeniek (2011). Językowi uczniów uczęszczających do jednej ze szkół polonijnych swoją pracę poświęciła Jędryka (2012). Lipińska (2013) w ramach studium przypadku badała, na jakim etapie opanowywania języka docelowego jest dziecko imigranckie po kilku latach pobytu w Australii, a w jakim stopniu włada językiem ojczystym (polskim). Na podstawie opracowanych przez nią testów można prognozować proces adaptacyjny ucznia $\mathrm{w}$ razie powrotu do kraju. Kompetencji leksykalnej użytkowników języka odziedziczonego z różnych krajów przyglądała się Seretny (2011), stwierdzając, że zasobność ich słownika na poziomie B jest często ograniczona do wyrazów najczęściej używanych, a i tu miewają braki. Inne zagadnienie, nowe w literaturze przedmiotu, czyli atrycję języka odziedziczonego przybliżyły Libura (2014) oraz Żurek (2016), a badania na szerszą skalę u użytkowników niemieckojęzycznych ${ }^{22}$ przeprowadził zespół pod kierownictwem Dąbrowskiej (zob. Besters-Dilger, i in. (red.) 2016). Pułaczewska (2016) natomiast próbowała wyłonić najistotniejsze czynniki środowiskowe, socjodemograficzne i kognitywne wykazujące ich korelacje z wiedzą o Polsce i kompetencją językową w JOD.

W analizach wykorzystano rozmaite narzędzia badawcze, w części jednak pozwalały one na wskazanie nie tyle faktycznego, ile deklarowanego poziomu umiejętności językowych: dzieci pytane były o preferencje używania każdego z języków, a ich rodzice, dziadkowie i nauczyciele - o ocenę umiejętności językowych dzieci (zob. m.in. Rabiej 2007; Dębski 2009). Prace takie są cenne i ważne, lecz nie pokazują stanu rzeczywistych kompetencji językowych badanych.

Komparatywne badania kompetencji należą do rzadkości, tymczasem porównanie umiejętności językowych osób, które posługują się na co dzień dwoma kodami przyczyniłoby się do znacznego poszerzenia wiedzy o bilingwizmie,

${ }^{21}$ Autor prowadzi obecnie badania kompetencji fonologicznej dzieci ukraińskich opanowujących polszczyznę.

${ }^{22}$ Umiejętności niemieckojęzycznych użytkowników języka polskiego jako odziedziczonego bada aktualnie zespół kierowany przez Brehmera (Universität Greifswald). Realizuje on projekt Sprachbewusstheit und Mehrsprachigkeit. Entwicklung einer ressourcenorientierten Didaktik für den Herkunfts und Fremdsprachenunterricht am Beispiel russische und polnischer Herkunftssprecher innen, finansowany przez niemieckie ministerstwo Bundesministerium für Bildung und Forschung. 
szczególnie kognitywnym, rzadziej poddawanemu analizom. Pozwoliłoby to nie tylko na lepsze zrozumienie samego zjawiska, lecz także umożliwiłoby pełniejszą charakterystykę JOD dzięki:

- wskazaniu obszarów deficytowych użytkowników języka odziedziczonego (ujęcie zagadnienia w kategoriach ilościowych i jakościowych);

- wskazaniu potencjalnych zagrożeń (np. półjęzyczności, interjęzyka o cechach pidżynu, zamrożonej kompetencji w języku docelowym ${ }^{23}$ ).

Ze względu na wagę problemu testy powinny by zostać przeprowadzone najpierw w środowisku o jednorodnej charakterystyce, czyli wśród Polonii kanadyjskiej, amerykańskiej lub australijskiej, których język jest bardziej ustabilizowany niż język polonijnych wspólnot europejskich, np. na Wyspach Brytyjskich, w Irlandii, w Niemczech czy w Szwecji. Czynnikami stabilizującymi - w przypadku krajów odległych - są:

- niska w ostatnich dziesięcioleciach atrakcyjność tego kierunku migracyjnego, czego skutkiem jest niewielka liczba dzieci, która się tam osiedla (dzięki temu społeczeństwo polonijne nie podlega znaczącym zmianom, można je badać wszerz i w głąb);

- oddalenie od Polski, które powoduje, że zarówno prawdziwe kontakty face to face (tj. nie za pośrednictwem skype'a czy innych komunikatorów), jak i zanurzenie w języku w czasie wyjazdów wakacyjnych, świątecznych czy weekendowych są ograniczone.

Sugerowane przez nas badanie dwujęzyczności kognitywnej koncentrować się powinno na działaniach produktywnych, receptywnych i mediacyjnych w obszarze sprawności manualno-wzrokowych. W modelach kompetencji komunikacyjnej (zob. m.in. ESOKJ 2003) pokazywane są one zazwyczaj jako jej odrębne elementy, jednak w czasie działań językowych bardzo trudno oddzielić je od siebie, ponieważ wiele z nich jest uruchamianych jednocześnie. Stopień opanowania języka należałoby oceniać na podstawie wypowiedzi pisemnych, w których istnieje wymóg używania języka standardowego (w odmianie oficjalnej). Dużą zaletą tego wyboru środka kontroli jest fakt, że pisemne próbki ${ }^{24}$ można poddawać wielokrotnym i wieloaspektowym analizom ilościowym i jakościowym. Wymierną korzyścią takich dociekań byłoby opracowanie kompleksowego narzędzia pomiaru kompetencji osób dwujęzycznych kognitywnie, które mogłoby być replikowane w różnych kontekstach.

Same badania musiałyby odbyć się w trzystopniowym porządku, obejmującym: 1. opracowanie i przygotowanie testów 2. przeprowadzenie ich (koniecznie przy obecności badacza), 3. analiza wyników i właściwa ich interpretacja. Istotne znaczenie ma też dobór reprezentatywnej próby, co może nie być łatwe, gdyż, po-

${ }^{23}$ Szerzej o tych zjawiskach zob. Lipińska 2003.

${ }^{24}$ Próbki ustne (nagrania) wymagają kłopotliwego i subiektywnego niekiedy transkrybowania. 
szukując respondentów, należy wziąć pod uwagę wiele zmiennych, które muszą być kompatybilne, np. wiek, poziom językowy, pochodzenie itp. Wydaje się, że liczbę graniczną badanych grup powinno się ustalić na 50 osób.

Trzeba pamiętać, że zasadniczym celem poznania naukowego, które z definicji powinno być utylitarne, twórcze, systematyczne, obiektywne i sprawdzalne, jest zdobycie wiedzy pewnej, dokładnej i możliwie jak najściślejszej (zob. Lipińska, Seretny (w druku)).

\section{WNIOSKI}

W glottodydaktyce koniecznością stało się odróżnianie dwóch rodzajów dwujęzyczności: naturalnej i kognitywnej. Osiągnięcie drugiej jest możliwe dzięki nauce w polskich/polonijnych placówkach, gdzie dochodzi do wczesnego, regularnego i intensywnego kontaktu ze standardową polszczyzną szkolną, a więc język ma szansę rozwijać się w pełnym wymiarze i być nie tylko środkiem komunikacji, ale stawać się także coraz doskonalszym narzędziem poznawania świata. Sprawne posługiwanie się nim w mowie i w piśmie jest niezwykle ważne w przypadku reemigracji, ponieważ większość powracających/przyjeżdżających uczniów posiada jedynie naturalną znajomość polszczyzny zagranicznej. To sprawia, że nie powinni być traktowani jak użytkownicy rodzimi, gdyż uboższa, nieadekwatna do wieku i poziomu nauczania polszczyzna może łatwo stać się powodem ich porażki w szkole. Podłoża takich problemów nie są świadomi ani nauczyciele, ani rodzice, którym wiedza płynąca z badań pozwoliłaby zrozumieć specyfikę obu rodzajów dwujęzyczności. Stanowiłaby też namacalny dowód, że transmisja polskości na obczyźnie jest konieczna, a dbałość o poziom polszczyzny sprzyja powstaniu bilingwizmu kognitywnego. Wyniki analiz stopnia znajomości języka polskiego jako odziedziczonego w porównaniu z językiem ojczystym Polaków w Polsce i równolatków w kraju osiedlenia byłyby ważne nie tylko dla świata nauki, lecz także, w wersji popularno-naukowej, dla polskich i polonijnych instytucji troszczących się o utrzymanie/zachowanie języka w polskiej diasporze.

\section{BIBLIOGRAFIA}

Besters-Dilger J., Dąbrowska A., Krajewski G., Żurek A., (red.), 2016, Utrata i odzyskiwanie języka polskiego. Językoznawcze i glottodydaktyczne aspekty niepetnej polsko-niemieckiej dwujęzyczności, Łask.

Bernstein B., 2003, Class, Codes and Control, t. 1, London.

Bieńkowska D., 1974, Metody nauczania języka polskiego w szkołach podstawowych w Kanadzie - garść uwag i sugestii, „Biuletyn ZNP”, Wiosna. 
Cieszyńska J., 2006, Dwujęzyczność, dwukulturowość - przekleństwo czy bogactwo? O poszukiwaniu tożsamości Polaków w Austrii, Kraków.

Czeniek A., 2011, Stopień opanowania sprawności pisania przez dzieci polonijne uczące się w Polskich Szkołach Sobotnich w Wielkiej Brytanii, niepublikowana rozprawa doktorska, Wydział Polonistyki UJ, Kraków.

Czykwin E., Misiejuk D., 2002, Dwujęzyczność i dwukulturowość w perspektywie psychopedagogicznej, Białystok.

Dębski R., 2009, Dwujęzyczność angielsko-polska w Australii. Języki mniejszościowe w dobie globalizacji i informatyzacji, Kraków.

Dębski R., 2015, Phonological patterns in the speech of Polish English bilingual children in Australia. Initial findings, „LingVaria”, nr 2(20), s. 27-40.

Dubisz S. (red.), 1997, Język polski poza granicami kraju, Opole.

ESOKJ: Europejski system opisu kształcenia językowego: uczenie się, nauczanie, ocenianie, 2003, Warszawa.

Fishman J. A., 2001, 300-Plus Years of Heritage Language Education in the United States, w: J. Kreeft, Peyton, D. A. Ranard, S. McGinnis (red.), Heritage Languages in America. Preserving a National Resource, Illinois, s. 81-99.

Gębal P. E., 2018, Podstawy dydaktyki języka polskiego jako drugiego. Podejście integracyjno-inkluzyjne, Kraków.

IEL: International Encyclopedia of Linguistics, W. Bright (red.), New York, 1992.

Janowska I. i in. (red.), 2011, Programy nauczania języka polskiego jako obcego. Poziomy A1-C2, Kraków.

Jędryka B., 2012, Język polski w szkole polonijnej, Warszawa.

Kurcz I. (red.), 2007, Psychologiczne aspekty dwujęzyczności, Gdańsk.

Kurcz I., Okuniewska H. (red.), 2011, Język jako przedmiot badań psychologicznych, Warszawa.

Laskowski R., 2009, Język w zagrożeniu. Przyswajanie języka polskiego w warunkach polsko-szwedzkiego bilingwizmu, Kraków.

Libura A., 2014, Atrycja języka odziedziczonego, w: A. Dąbrowska, U. Dobesz (red.), 40 lat wrocławskiej glottodydaktyki polonistycznej. Teoria i praktyka, Wrocław, s. 297-306.

Lipińska E., 2003, Język ojczysty, język obcy, język drugi. Wstęp do badań dwujęzyczności, Kraków.

Lipińska E., 2007, Między 'emigracja' a 'Polonia'- pierwsze pokolenie polonijne, „Prace Filologiczne", t. LIII, s. 355-363.

Lipińska E., 2013, Polskość w Australii - o dwujęzyczności, edukacji i problemach adaptacyjnych Polonii na antypodach, Kraków.

Lipińska E., 2014, Dwujęzyczność pokolenia polonijnego - jak ja zdobyć i zachować, „Polski w Niemczech. Pismo Federalnego Związku Nauczycieli Języka Polskiego", nr 2, s. 5-8.

Lipińska E., 2015a, Dwujęzyczność kognitywna, „LingVaria”, nr 2(20), s. 55-68.

Lipińska E., 2015b, O transmisji polskości w Australii, w: Szkolnictwo polskie poza granicami Rzeczypospolitej po roku 1918, Polski Uniwersytet na Obczyźnie, Londyn, Zeszyty Naukowe, seria trzecia, nr 3, s. 269-280.

Lipińska E. (w druku), Język polonijny czy języki polonijne? „Postscriptum Polonistyczne”, 2019.

Lipińska E., Seretny A., 2012a, „Język odziedziczony” w szkołach polonijnych, „Głos Nauczyciela”, r. XXVII, nr 1, s. 65-68.

Lipińska E., Seretny A., 2012b, Między językiem ojczystym a obcym. Nauczanie i uczenie się języka odziedziczonego w chicagowskiej diasporze polonijnej, Kraków.

Lipińska E., Seretny A., 2012c, Między dydaktyka języka ojczystego a obcego - nauczanie języka polskiego w szkołach polonijnych w Stanach Zjednoczonych, w: B. Skowronek (red.), (Nie) swój język polski. Nowe horyzonty w językoznawstwie stosowanym, Kraków, s. 78-95.

Lipińska E., Seretny A., 2012d, Szkoła polonijna czy językowa? Szkolnictwo polonijne w perspektywie dydaktycznej, „Studia Migracyjne - Przegląd Polonijny”, nr 4, s. $23-37$.

Lipińska E., Seretny A., 2012e, Uczący się języka polskiego jako obcego/drugiego w środowisku endolingwalnym - ich umiejętności i potrzeby, „Kwartalnik Polonicum”, nr 1, s. 2-10. 
Lipińska E., Seretny A., 2017, Rozwijanie kompetencji językowych na bazie tekstów kultury - o ksztatceniu językowo-literackim w wariancie skorelowanym, „Uczymy, jak uczyć. Kwartalnik Wspólnoty Polskiej”, 2017, nr 1-2, s. 19-22.

Lipińska E., Seretny A. (w druku), Ankieta jako metoda zbierania danych ilościowych. Badania w ramach projektu ,Polish your Polish" - refleksje post rem, Opole.

Luk G., Bialystok E., 2013, Bilingualism is not a categorical variable: Interaction between language proficiency and usage, „Journal of Cognitive Psychology”, s. 1-17.

de Mejía A.-M., 2002, Power, Prestige, and Bilingualism: International Perspectives on Elite Bilingual Education; on-line: searchworks.stanford.edu/view/4780297 [10.02.2015].

Miodunka W., 2003, Bilingwizm polsko-portugalski w Brazylii: w stronę lingwistyki humanistycznej, Universitas, Kraków.

Miodunka W., 2010, Polszczyzna jako język drugi. Definicja języka drugiego, w: J. S. Gruchała, H. Kurek (red.), Silvarerum philologicarum. Studia ofiarowane Profesor Marii Strycharskiej-Brzezinie z okazji Jej jubileuszu, Kraków, s. 233-245.

Miodunka i in. (red.), 2018, Nauczanie i promocja języka polskiego w świecie. Diagnoza i perspektywy, Katowice.

Montrul S., 2013, How “Native” are Heritage Speakers?, „Heritage Language Journal”, nr 10, s. $153-177$.

Petitto L. A., 2009, New discoveries from the bilingual brain and mind across the life span: Implications for education, „Mind, Brain, and Education”, nr 3(4), s. 185-197.

Polish your Polish - Badania i popularyzacja języka polskiego wśród Polonii amerykańskiej, 2016, Nowy Jork-Warszawa.

Polinsky M., 1997, American Russian: language loss meets language acquisition, http://scholar. harvard.edu/files/mpolinsky/files/American_Russian_Language_Loss_Meets_Language_ Acquisition.pdf?m=1360038984 [11.12.2016].

Polinsky M., Kagan O., 2007, Heritage languages: in the 'wild' and in the classroom, „Language and Linguistics Compass", nr 1(5), s. 368-395.

Pułaczewska H., 2016, Środowiskowe korelaty znajomości języka polskiego wśród młodzieży polskiego pochodzenia w Ratyzbonie, „Kwartalnik Pedagogiczny”, nr 4, s. 116-136.

Rabiej A., 2007, Specyfika nauczania języków obcych dzieci na przykładzie języka polskiego jako obcego, niepublikowana rozprawa doktorska, Wydział Polonistyki UJ, Kraków.

Seretny A., 2011, Kompetencja leksykalna uczacych się języka polskiego jako obcego w świetle badań ilościowych, Kraków.

Seretny A., 2015, Słownictwo w dydaktyce języka. Świat słów na przykładzie języka polskiego, Kraków.

Seretny A., Lipińska E., 2016, Polish as a Heritage Language - Somewhere in between, „Studia Migracyjne - Przegląd Polonijny", z. 2(160), s. 177-201.

Sękowska E., 1994, Język zbiorowości polonijnych w krajach anglojęzycznych: zagadnienia leksykalno-stowotwórcze, Warszawa.

Skutnabb-Kangas T., 1981, Bilingualism or not: The Education of Minorities, Multilingual Matters, London.

Valdés G., 2000, The teaching of heritage languages: an introduction for Slavic-teaching professionals, w: O. Kagan, B. Rifkin (red.), Teaching and Learning Slavic Languages and Cultures, Bloomington, Indiana, s. 375-402.

Valdés G., 2001, Heritage language students: Profiles and possibilities, w: J. K. Peyton, D. A. Ranard, S. McGinnis (red.), Heritage languages in America: Preserving a national resource, CAL, McHenry, IL, s. 37-77.

Warchoł-Schlottmann M., 1994, Próba opisu kompetencji językowej w niemieckim i polskim u Polaków $w$ Niemczech - studium socjolingwistyczne, niepublikowana rozprawa doktorska, Kraków.

Wodniecka Z., 2011, Dwujęzyczność. Właściwości dwujęzycznego umyslu i specyfika psychologicznych badań nad dwujęzycznościa, w: I. Kurcz, H. Okuniewska (red.), Język jako przedmiot badań psychologicznych, Warszawa, s. 253-284. 
Wodniecka Z., Haman E., 2013, Dwujęzyczność - wyzwanie, które warto podjać, czyli co o dwujęzyczności mówi psychologia, http://www.euroemigranci.pl/dokumenty/pokonferencyjna/Wodniecka_Haman.pdf [15.12.2014].

Wróblewska-Pawlak K., 2004, Język - tożsamość - imigracja. O strategiach adaptacyjnych Polaków zamieszkatych we Francji w latach osiemdziesiatych XX wieku, Warszawa.

Żurek A., 2016, Badanie polszczyzny odziedziczonej (na przykładzie bilingwizmu polsko-niemieckiego), „LingVaria”, nr 1(21), s. 191-202.

Ewa Lipińska, Anna Seretny

\title{
HERITAGE LANGUAGE AND BILINGUALISM - THE NECESSITY OF COMPARATIVE RESEARCH STUDIES
}

Keywords: heritage language, cognitive bilingualism, necessity of comparative research

\begin{abstract}
Due to global social and economic changes the educational past and language biographies of Polish migrant children are currently more complex. Observations and research prove that a significant ratio of these children are bilingual. They learn the majority code relatively fast and at the same time they acquire/maintain Polish, their heritage language (HL). The level of their competency in Polish varies, however, due to limited contact with it and "little practice". Most of the young migrants are therefore naturally bilingual, only rarely however may they boast cognitive bilingualism.

In the paper, we analyze the phenomenon of bilingualism placing it in the learning/teaching perspective. We also emphasise the necessity of conducting comparative research into language competences of Polish bilingual teenagers. Such research would considerably expand our knowledge of bilingualism, in particular of the rarely studied cognitive form. It should also show a more systematic and thorough description of HL itself as a phenomenon situated somewhere 'in between' a native language and a foreign one. The results of such research would be applicable not only in socio-, psycho- and applied linguistics and pedagogy, but also in the sphere of education.
\end{abstract}

